\title{
The East Side Story of Gender and Feminism
}

\section{The Hungarian and Czech Cases}

\author{
Review essay by Gabriela Dudeková Kováčová
}

Judith Szapor, Hungarian Women's Activism in the Wake of the First World War: From Rights to Revanche, New York: Bloomsbury Academic, 2018, 207 pp. 102.60 USD (hardback), ISBN 978-1-350-02049-8.

Iveta Jusová and Jiřina Šiklová, eds., Czech Feminisms: Perspectives on Gender in East Central Europe, Bloomington: Indiana University Press 2016, 325 pp., no price listed (hardback), ISBN 978-0-25302-189-2.

Recent publications on women's and gender history in Central and Eastern Europe have credibly contested the simplified idea that the region experienced the same processes as Western Europe and the United States, but with a time lag. Such authors' projections stemmed mainly from their lack of knowledge of the different cultural and political contexts in Central and Eastern Europe, which were decisive for the structure of the gender order and culture in various regions of Europe and the world. Robust case studies of individual regions and states create a solid base for further comparison. They allow for the comparison of cultural contexts and political regimes, which created the differences in gender cultures and in the local politics of gender order. Two new works that take into account specific local contexts include Judit Szapor's book on women's activism in Hungary shortly before and after World War I, as well as a collection of essays dealing with gender, feminism, and ethnicity issues in the Czech cultural and political context, edited by Iveta Jusová and Jiřina Šiklová.

In the first book under review, historian Judit Szapor, an associate professor at McGill University in Toronto, focuses on the specific features of the changing political regimes in Hungary after World War I, questioning the role of the women's movement and women's activists in this turbulent period. She aims to characterize the changes in the politics of the gender order and the role of women's activism in it, comparing the prewar and postwar periods in Hungary. She chose the book's subtitle, From Rights to Revanche, as emblematic for such substantial shifts, which she evaluates as a "change 
from liberal to an illiberal political framework and dominant ideology during the interwar period" (14). As far as chronology is concerned, Szapor frames her analysis around two significant events deeply connected with Hungarian women's movements: the Seventh Congress of the International Woman Suffrage Alliance (IWSA) in Budapest in June 1913 and the symbolic beginning of the new extreme right-wing regime supported by the most conservative right-wing women's movement in Hungary - the triumphant entry in November 1919 of Miklós Horthy, head of the strongly anti-liberal authoritarian regime in Hungary after the war, in Budapest as the future Regent of the Kingdom, and the greeting given him by leaders of the right-wing National Association of Hungarian Women on this occasion (4). But, the time frame of the book is slightly different, and it is defined in a somewhat confusing way in the introduction. Szapor claims that "this study sets the period between 1913 and 1922" (6). However, she deals with the shorter period: "the timeframe of its core is even shorter, limited to the years between the end of 1917 and the beginning of 1920." Szapor clarifies the narrowed time period: "The first date marks the beginning of the last, unsuccessful suffrage campaign; the second the elections in which Hungarian women voted for the first time" (6). Szapor explains these two types of time framing as "the broader-1913 to 1922 and narrowed-late 1917 to early 1920" (8). Regardless, her main focus in the book is on the immediate postwar period.

We must definitely agree with the author's claim that there is a "persistent blind spot for women" in the historiography on the turbulent postwar period in Hungary (11), and little research has been done on women's public activism during the postwar leftist revolution and further regime changes. Szapor's ambition to widen her original plan of a "first comprehensive study of right-wing women activists" is most welcomed. In her book, she presents an extended "history of the three main strands-liberal feminists, conservative-nationalist, and socialist-of women's activism in Hungary," while asserting her work "is not only the first to offer their detailed history but also the first that considers their dynamics with one another and the broader political context" (8). For example, she not only examined the materials of Rosika Schwimmer's papers in the New York Public Library, but she also compared them to the published memoires of the noble elite activist Katinka Károlyi and ego-documents of several leftist female personalities from the Archive of the Institute of Political History in Budapest. Using these materials, the author reveals new facts and connections among women's activists across the broad political spectrum.

In the first chapter, Szapor briefly characterizes the forms, particular ideological streams, and personalities of the women's movement in Hungary until 1918. As an initial milestone she uses the year 1904, when the most radical liberal feminist association, the Feministák Egyesülete (Association of Feminists, or FE) in Hungary, was founded. In my opinion, in dealing with the FE and its specifics, it should be more emphasized that its members were both women and men. The original name in Hungarian, Feministák Egyesülete, also refers to this: while the original term "feminist" in the Hungarian language is gender neutral, it includes both genders. It is indisputable that the FE managed to push the modern feminist agenda into public discourse and from the very beginning to establish cooperation with the international women's movement. Thanks to the FE, the 1913 Congress of IWSA was held in Budapest, and 
the members of the FE constituted an organizing committee of the Congress. However, Szapor should be more cautious when assessing the impact of the FE in the prewar period. It is true that media coverage of the FE's activities (including the IWSA Congress in Budapest) and its strong personalities, such as Róza Bédy Schwimmer, caused the FE to gain public attention. But to treat the FE as "mainstream" (18) is an exaggeration. We have to consider that conservative charitable and religious women's associations were the most popular and had the largest membership within the broad spectrum of women's associations in Hungary. The increase in the number of FE members occurred only in the last phase of the war due to the agitation of the FE in the countryside, and especially because of its pro-peace activities. Through this agenda, along with social requirements, it was possible to overcome the strict ideological differences between the middle-class-based FE and left-wing women's activists, and for a short while also the national women's activists from ethnic minorities. At that time, for example, radical Slovak nationalist feminist Hana Gregorová joined the FE. However, there are no exact comparable data for the numbers of members of particular women's organizations, and the impact of conservative streams of female activism in Hungary remained dominant.

The following five chapters form the core of the work, outlining the characteristics of new options and burdens for women's activism depending on the transforming political regimes in the short period following October 1918, that is, from the revolutionary establishment of the more liberal Károlyi government through the communist coup that established the Hungarian variant of the Bolshevik "Republic of Councils" and finally to the extremely conservative right-wing regime of Miklós Horty. The indisputable contribution of the book is that it summarizes the facts about the different streams of the women's movement and its prominent personalities, taking into account their interactions. However, some parts of the interpretation need clarification. Since the author's ambition was a comparison of the prewar and postwar period, the book requires a deeper analysis of the changes during the war. The author's statement that the prewar regime in Hungary was liberal and favorable to women's associations is only valid to a certain extent. From a comparison with the post-1918 situation, Szapor concludes: "The prewar period represented the first and last time in Hungary's modern history when, within a rich associational life, various streams of women's movements coexisted in a peaceful manner" (24). We can agree with Szapor that the prewar regime in Hungary was the most liberal regime in the history of Hungary, but it was definitely not democratic. Szapor herself argues, during the regime of the Kingdom of Hungary, "the working class and even intellectuals, were barred from Parliament by an antiquated electoral system designed to keep the national minorities, the working class, and the peasantry out" (23-24). With regard to freedom of association-and this is contrary to Szapor's assertion - the prewar regime's associations policy applied special discriminative regulations to workers' associations and associations of nonHungarian nationalities (for example, the state prohibited them from establishing branch offices). And it was this state control policy toward potentially oppositional associations (and, of course, because of their common anti-war agenda) that brought together the previously disparate FE and leftist women's associations during the war. During the war, the Hungarian associations that had been inimical - the radical femi- 
nist and sociodemocratic ones - became closer to each other, being under the same discrimination imposed by the authoritarian war regime. War was a starter and catalyst for several processes, also in connection to women's activism and the issue of citizenship, which should have been analyzed deeper. Nevertheless, anyone who wants to study or do research on women's movement activities in connection with the specific regime after World War I in Hungary and Central Europe should definitely read this book.

In the final concluding chapter, Szapor considers the long-term legacy of interwar female activism and its ideas. She opens the question of why today there is still a "long-lasting connection between extreme nationalism, perceived national interest, and illiberal gender values" (14). In her opinion, "this connection, forged in the immediate aftermath of the First World War by right-wing women activists, has outlived them by a century and constitutes their true legacy" (14). She points out that "illiberal family and gender values have been part and parcel of every right-wing, nationalistic political creed" (149). However, these ideas were present also in the later historical periods, including under the communists.

Some answers to the question about the resistance of illiberal anti-feminist values raised by Szapor can be found in the collection of sixteen essays on women's and gender issues dealing with Czech feminism. The aim of the authors and editors of the book is quite ambitious. As stated in the introduction: "In planning and organizing this book project, we started from a conviction that an expanded engagement with the intersection of gender, sexuality, and ethnicity issues in the Czech context, combined with a contextualizing attention to the broader Eastern/East Central European location, might offer a positive contribution to current transnational Gender Studies debates" (3). At the same time, they want "to add productively to existing feminist debates, hopefully lending useful expansion to the existing transnational feminist discourse" (4). As the subtitle of the book suggests, the team of authors presents quite diverse views of gender within East Central Europe.

In the introductory chapter, one of the editors, Iveta Jusová, presents the common grounds of the individual essays in the book and several key themes that helped organize this collective work: the idea of Eurocentrism, ethnicity, state socialist gendered subjectivities, post-1989 specificities, LGTB expressions and inflections, and Czech language with regard to gender-fair language use. There is also a brief historical overview of Czech women's emancipation and women's issues since the nineteenth century through the twentieth century, including Czechoslovak state socialism in the post-1989 period.

The book is divided into two parts: "Gender issues in Czech society" prior to 1989 and post-1989, with 1989 referring to the fall of the communist regime in Czechoslovakia. However, most of the book focuses on the postcommunist period and the present situation. In the first "historical" part, Jitka Malečková discusses key concepts of the Czech women's movement and emancipation, specifically the intersection of gender and nationalism. An expert on national and gender studies, she deals with the common problems of the many national women's movements within Central and Eastern Europe, raising the question of whether the ideology and practice of nationalism helped to promote women's emancipation and gender equality. An important element in her study is the concept of colonialism applied in relation to Czech nationalism in 
the nineteenth and early twentieth centuries. An essay by Karla Huebner reveals the work and attitudes of an extravagant female painter in the 1920s and 1930s, a member of the Czech avant-garde who used the pseudonym Toyen, a gender-neutral name that "also functioned as a de-gendering strategy" (65). To accentuate her gender neutrality this artist used to speak in the masculine gender and even dressed in a masculine style. Two chapters, written by Alena Wagnerová and Pavla Frýdlová, deal with the status of women and the limits of gender equality during the era of state socialism in Czechoslovakia.

An important insight into the situation of feminism in Czech society in the early 1990s is provided by Simona Fojtová in her introductory chapter to the second, "post1989," part of the book. Comparing feminism with the communist model of women's emancipation and with the situation in other Western and Eastern European countries, Fojtová's essay and conclusions presented here (which contradict Wágnerová's outcomes to some extent) is a robust contribution to the debate on the communist legacy in relation to feminism and gender equality in the broader regional context. As in other Eastern European countries, the position of feminism changed during the last two decades in the Czech Republic. Fojtová underlines: "Among the former socialist countries, Czechoslovakia became associated with the most pronounced resistance to Western-style feminism" (114). But nowadays, "the changing academic, social, and cultural landscapes reflect growing gender consciousness and a feminist ethos ... In contrast to 1990s, the new millennium has offered a steady growth in Czech feminist scholarship, a burgeoning institutionalization of Gender Studies programs of Czech universities, and an increased presence and influence of women's nongovernmental organizations" (115). She argues that the public media changed their attitudes to feminist issues radically: "The post-1989 attacks on feminism in Czech media have lost much of their original vitriol as well as mass support, and in the past several years the Czech mainstream press has even started featuring pro-feminist articles. This change is also evident in other post-socialist countries" (115). Fojtová reevaluates the East/ West debates on feminism and its applicability to the postcommunist societies in the 1990s. In Fojtová's opinion, “Czech women's experience with socialism did not necessary lead to their perceived rejection of feminism; rather, these experiences exposed the limitations of the applicability of liberal Western feminism to the Czech context." So, she comes to the conclusion: "Contrary to the dominant academic assessments, I argue that their critiques should not be seen as a rejection of feminism but as a call for a cultural and political situatedness of feminist analysis relevant to Czech women" (116). Specifically, for Eastern Europe feminist studies, she proposes intersectional theory and situatedness for feminist analysis, but not as Western feminist analyses do, focusing only on "how gender intersects with race, class, sexuality, ability, and other identity markers." In postsocialist countries, "issues of nationality and the role of the state, and especially the communist regime" have to be analyzed. "The prevalent Western focus on race, class, and gender as an intersecting lines of oppression does not necessarily provide the relevant framework for Czech women since difference stems from the political systems of communism and nationalism" (120).

The subsequent essays focus on women's organizations in the Czech Republic, the intersection of ethnicity and feminism, and problems of nonhegemonic gender 
models: a long-term study of women's NGOs in the Czech Republic since the 1990s (by Hana Hašková and Zuzana Uhde); an essay on "Czech anarcho-feminism" that seeks to combine anarchist and feminist ideas (by Linda Sokačová); an interesting insight into the "aspects of sex and gender in Romany communities" (by Karolína Ryvolová) as well as among the Vietnamese communities in the Czech Republic (by Mária Strašáková); contributions dealing with previously taboo topics, sex trafficking and sex work (by Simona Fojtová) as well as the LGBT community in contemporary Czech society (by Kateřina Nedbálková); and a sociological essay dealing with the situation of elderly and retired women (by Jiřina Šiklová). The volume also includes very inspiring contributions to the discussion on gender and masculinities: a study of male doctors in maternity wards (by Iva Šmídová); an essay dealing with ways of using gender-fair language in the case of Czech (and other Slavic languages), which are gender-biased in their very grammar structures (by Jana Valdrová); and an essay on gender in contemporary art (by Zuzana Štefková).

Essays edited by I. Jusová, Professor of Women's and Gender Studies at Carleton College, and by sociologist and former anti-communist dissident J. Šiklová, a founder of the Gender Studies Center in Prague, apply the intersectional theory in an inspiring way in the analysis of gender issues in the past and in contemporary Czech society. While focusing on the context of the Czech Republic and former Czechoslovakia, several of them include comparisons to other Western and Eastern countries. Both reviewed books are important results of the latest research and make valuable contributions to debates on women's movements, women's activism, and the gender order and gender culture under different political regimes in the broader context of Central and Eastern Europe.

\section{$\diamond$ About the Author}

Gabriela Dudeková Kováčová is a Senior Researcher at the Institute of History, Slovak Academy of Sciences, Bratislava, Slovak Republic. In her research and publications, she focuses on social and cultural history of Slovakia in the context of the Habsburg monarchy and the Czechoslovak Republic in the long nineteenth century to the middle of the twentieth century, particularly gender history, social and cultural history of World War I, and history of social care and social policy. She is author and coauthor of publications in fields of women's and gender history in Slovakia, Czech Republic, and Hungary, including Na ceste k modernej žene: Kapitoly z dejín rodových vzt'ahov na Slovensku (Toward the modern woman: Chapters on gender history in Slovakia) (Bratislava: Veda, 2011). E-mail: gabriela.dudekova@savba.sk 